\title{
Outcomes and analysis of fetomaternal elements and delivery strategies with neonatal respiratory distress
}

\author{
Sambedna ${ }^{1}$, Amit Kumar ${ }^{2 *}$, Rita Chakore ${ }^{3}$
}

\begin{abstract}
${ }^{1}$ Department of Obstetrics and Gynecology, ${ }^{2}$ Department of Pediatric Surgery, AIIMS, Patna, Bihar, India
${ }^{3}$ Department of Obstetrics and Gynaecology, PMCH, Patna, Bihar, India
\end{abstract}

Received: 13 March 2021
Accepted: 12 April 2021

\author{
*Correspondence: \\ Dr. Amit Kumar, \\ E-mail: amitsandilya1981@gmail.com
}

Copyright: () the author(s), publisher and licensee Medip Academy. This is an open-access article distributed under the terms of the Creative Commons Attribution Non-Commercial License, which permits unrestricted non-commercial use, distribution, and reproduction in any medium, provided the original work is properly cited.

\begin{abstract}
Background: Perinatal asphyxia is one of the most important causes of morbidity and mortality in neonates. Perinatal asphyxia occurs in association with different maternal and fetal determinants. However, the relation of associated factors with perinatal asphyxia is not well studied. The aim of this study was to determine the association of maternofetal factors and mode of delivery with perinatal asphyxia in a tertiary care centre.

Methods: This was a retrospective comparative study conducted in department of OBG in tertiary care health centre. A total 200 newborns were selected for study out of which100 newborns were with asphyxia at birth as study group and 100 non asphyxiated newborns were taken as control group. Maternal factor like age, parity, gestational age and fetal factor like weight at birth and mode of delivery were studied to established association on perinatal asphyxia.

Results: Maternal factor like age, parity, gestational age had not significant relationship with perinatal asphyxia. Maximum number of babies delivered in both control and the study group were in the range of 2.6 to $3 \mathrm{~kg}$.In this study birth weight did not have significant relationship with perinatal asphyxia. Proportions of LSCS was comparatively higher in the study group though. The delivery mode did not have any statistically significant influence on the newborns affliction with birth asphyxia ( $p>0.05)$.

Conclusions: Findings of this study highlight the need for the better obstetrical care and awareness of the possible presence of the risk factors of PNA (perinatal asphyxia) among mothers and fetus, so that the incidence and complications of PNA could be prevented or at least appropriately managed. It can reduce the high incidence of morbidity and mortality due to birth asphyxia.
\end{abstract}

Keywords: Birth asphyxia, Delivery mode, Maternofetal factor

\section{INTRODUCTION}

Birth asphyxia continues to be the leading cause of perinatal mortality and developmental and neurological handicaps in both term and preterm infants. The occurrence of birth asphyxia is closely related to a number of maternal, fetal and obstetrical risk factors. Reduction in the incidence of asphyxia at birth requires identification of high risk factors, to envisage an appropriate and timely action in such cases. The present study attempts to find out the importance of selected maternal factor and fetal factors and mode of delivery on the incidence of neonatal asphyxia. About one-fourth of all neonatal deaths are caused by perinatal asphyxia in worldwide. Birth asphyxia is responsible for $23 \%$ perinatal deaths in low-income countries. This finding signifies that perinatal asphyxia is still a global burden. ${ }^{1-3}$ During perinatal asphyxia, as a result of primary energy failure (deprivation from high-energy reserves of phosphate), cell damage can take the form of cell necrosis, commonly referred to as primary cell death. The extent of the damage depends heavily on the length and the intensity of the ischemia-hypoxia. Moreover, cell damage can occur in another form. In other words, on recovery through resuscitation, progressive cerebral edema, excitatory amino-acid accumulation at cellular 
level, and a procedure entailing a decrease in oxygen consumption and cell metabolism (latent phase) may result in a programmed apoptosis caused by secondary energy failure, which in turn occurs as a result of the decrease in cell energy reserves due to malfunction of the mitochondria. ${ }^{4-6}$

\section{METHODS}

This was a retrospective comparative study of association between maternofetal determinant and mode of delivery in asphyxiated and non-asphyxiated baby in a tertiary level health care centre conducted between December 2013 to November 2015. Total 200 newborns were selected for study out of which100 newborn were with asphyxia at birth as study group and 100 newborns were with non-asphyxia as control group.

Maternal factor like age, parity, gestational age and fetal factor like weight at birth and mode of delivery were studied to established association on perinatal asphyxia. Details of birth data of each case were recorded in a predesigned Performa. Every delivery was attended by a neonatal resident who gave timely resuscitation to all the cases when required and recorded Apgar score at 1,5 and $10 \mathrm{~min}$. respectively.

Apgar score of $<7$ at $1 \mathrm{~min}$ was defined as neonatal asphyxia. All neonates were weighed naked on a lever actuated weighing scale to the nearest $20 \mathrm{~g}$. Gestation of each neonate was calculated from the last day of menstrual period and when not available then clinical and neurological criteria for assessment of gestational age was applied. Sample size was calculated using a single population proportion formula a systematic sampling technique was used to get all study units in the delivery unit of the hospitals. In this study, all babies with their mother were eligible to inclusion while babies who are suffering from major congenital anomalies or syndromes and preterm babies <35 completed weeks were excluded. Ethical clearance of the study was taken, vide letter no PMC/2013/2226. Informed consent was obtained for every patient. Statistical analysis was done using SPSS version 20 and chi square test.

\section{RESULTS}

Table 1: Age of mother in study and control group.

\begin{tabular}{|lll|}
\hline Interval & $\begin{array}{l}\text { No. of pts. in } \\
\text { study group }\end{array}$ & $\begin{array}{l}\text { No. of pts. in } \\
\text { control group }\end{array}$ \\
\hline $\mathbf{1 6 - 2 0}$ years & 29 & 32 \\
\hline $\mathbf{2 1 - 2 5}$ years & 55 & 57 \\
\hline $\mathbf{2 6 - 3 0}$ years & 15 & 11 \\
\hline 31-35 years & 1 & 0 \\
\hline $\begin{array}{l}\text { Mean value } \\
\text { (average) }\end{array}$ & 22.42 Years & 21.98 Years \\
\hline
\end{tabular}

The study included 100 patient in study (asphyxiated baby) and 100 patients in control group (nonasphyxiated) for this analysis. Table 1 shows age of mother in the study group ranged from 16 to 35 years and in the control group ranged from 16-30 years. Maximum number of patients were in 21-25 years age group both in case as well as control group. Mean age of mother in the study group -22.42 years. Mean age of Pts. in the control group -21.98 years.

Table 2: Parity.

\begin{tabular}{|lll|}
\hline & $\begin{array}{l}\text { No. of Pts in study } \\
\text { group }\end{array}$ & $\begin{array}{l}\text { No. of pts in control } \\
\text { group }\end{array}$ \\
\hline Primi & 41 & 36 \\
\hline Multi & 59 & 64 \\
\hline
\end{tabular}

P Value $>0.05$

Table 2 shows that in both the study group and the control group, multiparous women were more than the primiparous women, but there is no significant relationship between fetal asphyxia and maternal parity. $\mathrm{P}$ value was $>0.05$, hence, the difference in the study and the control group was statistically not significant.

Table 3: Gestational age.

\begin{tabular}{|lll|}
\hline Gestational & $\begin{array}{l}\text { No. of pts in } \\
\text { study group }\end{array}$ & $\begin{array}{l}\text { No. of pts in } \\
\text { control group }\end{array}$ \\
\hline 36-37 weeks & 5 & 4 \\
\hline $\mathbf{3 7 - 3 8}$ weeks & 33 & 23 \\
\hline $\mathbf{3 8 - 3 9}$ weeks & 52 & 39 \\
\hline $\mathbf{3 9 - 4 0}$ weeks & 10 & 34 \\
\hline $\begin{array}{l}\text { Avg. } \\
\text { gestational age }\end{array}$ & SD -0.73 & 39.63 weeks \\
\hline $\begin{array}{l}\text { P }>0.05 \\
\end{array}$ & SD -5.96 \\
\hline
\end{tabular}

Table 3 shows Maximum no. of patients in the study group and the control group were having 38-39 weeks of pregnancy. The Average gestational age of study group was 38.67 weeks \pm 0.73 (SD) The average gestational age of control groups was 39.63 weeks \pm 5.96 (SD). There is no significant relationship between perinatal asphyxia and gestational age.

Table 4: Weight at birth.

\begin{tabular}{|lll|}
\hline $\begin{array}{l}\text { Baby wt in } \\
\text { intervals }\end{array}$ & $\begin{array}{l}\text { No. of babies } \\
\text { delivered by pts. } \\
\text { of study group }\end{array}$ & $\begin{array}{l}\text { No. of babies } \\
\text { delivered by } \\
\text { pts. in control } \\
\text { group }\end{array}$ \\
\hline $\mathbf{1 . 5 - 2 . 0 ~ k g}$ & 5 & 11 \\
\hline $\mathbf{2 . 1 - 2 . 5 ~ k g}$ & 26 & 20 \\
\hline $\mathbf{2 . 6 - 3 . 0 ~ k g}$ & 56 & 52 \\
\hline $\mathbf{3 . 1 - 3 . 5} \mathbf{~ k g}$ & 13 & 17 \\
\hline $\begin{array}{l}\text { Average baby } \\
\text { weight }\end{array}$ & $2.69 \mathrm{Kg}$ & $2.65 \mathrm{Kg}$ \\
\hline $\begin{array}{l}\text { P }>0.05 \\
\text { SD }-0.39\end{array}$ & SD -0.46 \\
\hline
\end{tabular}


Table 4 shows Maximum number of babies delivered in both the control and the study group were in the range of 2.6 to $3.0 \mathrm{~kg}$. Average baby weight in the study group was $2.69 \mathrm{~kg} \pm 0.39$ (SD). Average baby weight in the control group was $2.65 \mathrm{~kg} \pm 0.46$ (SD). There is no significant relationship between birth weight and perinatal asphyxia.

Table 5 shows Maximum number of deliveries in both the study group and the control group were by vaginal route. Proportion of LSCS was comparatively higher in the study group though not statistically significant.

Table 5: Mode of delivery.

\begin{tabular}{|lll|}
\hline $\begin{array}{l}\text { Mode of } \\
\text { delivery }\end{array}$ & $\begin{array}{l}\text { No. of pts in } \\
\text { study group }\end{array}$ & $\begin{array}{l}\text { No. of pts in } \\
\text { control group }\end{array}$ \\
\hline Vaginal & 64 & 68 \\
\hline LSCS & 36 & 32 \\
\hline p $>0.05$ & & \\
\hline
\end{tabular}

\section{DISCUSSION}

The incidence of perinatal asphyxia is still high inspite of timely neonatal resuscitative measure. In the study by B Ghosh S, Mittal S. Kumar V. Dadhwal of AIIMS in 1999-2001, the mean maternal age of the study group was 27.19 years \pm 3.82 (SD) and of the control group was 26.73- years \pm 4.40 (SD). ${ }^{7}$ Here also the difference was not statistically significant (P 0.66) Saracoglu et al in 1999, studied NRBC count in fetal acidosis. ${ }^{8}$

In their study also, mean age difference between the study and the control was statistically not significant. Quaiser DH, Perwaiz M et al of Ziauddin university, Pakistan in 2006-08 studied the influence of maternal factors on the hematological parameters and perinatal asphyxia. ${ }^{9}$ They found that NRBC count/100 WBC and other hematologic parameters in women of age group 1527 years was not statistically different from that in the age group of $28-45$ years $(\mathrm{P}=0.07)$.

In the study by Boskabadi $\mathrm{H}$ et al in 2006-08, the difference in the mean age of Pts. having evidence of perinatal asphyxia and Pts. not having perinatal asphyxia was statistically not significant In our present study the case and the control group were comparable on the basis of age and thus any possible effect of maternal age on the perinatal asphyxia may be neglected with increasing parity, more fibroelastic tissue is deposited in the wall of the uterus. ${ }^{10}$

But this does not seem to hamper in any way the supply of nutrients via the placenta or the growth of the fetus In the study by B. Ghosh et al of AIIMS found the difference in parity between the study and the control group was not significant $(\mathrm{P}=0.82){ }^{7}$ In their study group, $42.3 \%$ were primigravida where as in the control group, $36.7 \%$ were primigravida. According to a study in Pakistan by Danish et al conclude that $\mathrm{P}$ value was 0.34 (not significant) Thus it rules out any effect of parity on perinatal asphyxia. ${ }^{9}$ we also found that there may be no effect of parity on perinatal asphyxia So we can rule out the effect of this parameter on perinatal asphyxia. Prematurity also pre-disposes to neonatal asphyxia because of immature lungs, immature central nervous system and use of sedatives by the mother to stop premature labour various studies done on effect of gestational age on perinatal asphyxia. Most of studies observe significant relationship.

Clifford concluded that increased perinatal mortality and its accompanying mental injuries are mainly due to birth asphyxia in premature infants. ${ }^{11}$ Macdonald et al reported prematurity to be the most significant predictor of asphyxia. ${ }^{12}$ Among the 100 patients in the study group and 100 patients in the control group, maximum patients had gestational age of 38-39 weeks.

Mean gestational age in the study group was 38.67 weeks \pm 0.73 (SD) and the mean gestational age in the control group was $39.63 \pm 5.96$ (SD). P value was $>0.05$, which means there was statistically no significant difference between the two groups Gestational age has effect on NRBC count of cord blood which further reflects in form of perinatal asphyxia. Absolute NRBC count decreases with advancing gestation and increasing birth weight. It is reasonable to conclude from the previous studies that the mean NRBC/100 WBC in the first few hours of life in healthy term newborn is about $0-10$ and values above $10-$ 20 are considered elevated. Studies have consistently shown that NRBC decreases as the gestational age increases, except in the case of post term infants, who have higher count than the term infants. In preterm, the number of NRBC is higher and also persists longer compared with the term neonates.

In previous studies, like a study by B. Ghosh et al of AIIMS, India, the mean gestational age in the study group was 273.15 days \pm 8.83 (SD) and in the control group was 272.40 days \pm 7.76 (P 0.714). ${ }^{7}$ The difference was statistically not significant. In the study by Dasari Papa et al of JIPMER, India, the mean period of gestation in the study group was $272.69 \pm 34.27$ and in the control group was, $274.75 \pm 7.45$ (P 0.150). ${ }^{13}$ The difference in the period of gestation between the study and the control group was statistically not significant. Boskabadi $\mathrm{H}$ et al studied NRBC in cord blood in case of neonatal asphyxia. $^{10}$

In their study, the mean gestational age was 37.9 weeks \pm 1.5 in the study group and 39.1 weeks \pm 1.6 in the control group (P 0.068), difference was not significant statistically. Thus, we decided that possible effect on the count of NRBC which further reflect perinatal asphyxia resulting from the difference in the gestational age in the two groups could be neglected. Another causative factor for perinatal asphyxia was fetal birth weight. Neonates who are weighed less than $2.5 \mathrm{~kg}$ were prone to develop birth asphyxia which is consistent with studies from other corners of the world. ${ }^{14,15}$ In contrary, a large size of a 
baby at birth (a proxy for birth weight) had been found an associated factor for birth asphyxia-related neonatal mortality. ${ }^{16}$

Batra et al report maximum incidence of asphyxia at 32 weeks of gestation and at birth weight of <1500g. ${ }^{17}$ An increasing incidence of asphyxia with decreasing birth weight and a significantly increased incidence in small for date babies also compares well with the previous findings. But some studies showed insignificant relationship between birth weight and perinatal asphyxia. In the study by Saracoglu et al acute and chronic fetal distress, the average birth weight was $3211 \mathrm{~g} \pm 413$ (SD) in the control group. ${ }^{8}$ Among the chronic fetal distress group, the average baby weight at birth was $2571 \mathrm{~g} \pm 608$ (SD) and in the acute fetal distress group, the baby weight was $3259 \pm 452$ (SD).

Their result was comparable to a large extent with the present study's result. Minor variations may be due to the difference in the socioeconomic status or genetic or ethical difference between the populations studied. In the study by B. Ghosh et al the average baby weight in the study group i.e. the asphyxiated group was $2.8 \mathrm{~kg} \pm 0.5$ (SD) and in the control group, it was $2.8 \mathrm{~kg} \pm 0.47$ (P 0.799). ${ }^{7}$ The difference was statistically not significant. In the study by Boskabadi $\mathrm{H}$ et al on neonatal asphyxia in 2006-08, the average baby weight in the asphyxiated group was $2920 \mathrm{gm} \pm 405$ (SD) and in the control group, it was $3070 \mathrm{gm} \pm 416$ (SD). ${ }^{10} \mathrm{P}$ value was 0.397 which was statistically not significant. In this study the average baby weight in the study group was $2.69 \mathrm{~kg} \pm 0.39$ (SD) and the average baby weight in the control group was $2.65 \mathrm{~kg} \pm 0.46(\mathrm{SD})$.

The difference in the mean values was statistically not significant $(\mathrm{P}>0.05)$. Thus we can see that in the various studies in the past and also in this study the effect of birth weight on perinatal asphyxia can be ruled out. This may be due to small sample size. So we can conclude that birth weight is in no way affecting the result of this study. Caesarean section was also strongly associated with birth asphyxia in comparison to vaginal delivery and various studies supported it with diferent study designs. ${ }^{18-20}$ This finding was consistent with those of studies conducted in Gusau, Nigeria, Combined Military Hospital Multan, Pakistan, Dr Soetomo Hospital Surabaya, Indonesia and Valieasr hospital, Tehran, Iran where the odds of birth asphyxia among fetus delivered by Caesarean were about 2 to 20 times higher compared to newborns who were born through spontaneous vaginal delivery. ${ }^{21-24}$

The high rate of asphyxia among newborns delivered by CS might be due to the fact that either most of the mothers came with complications or the late decision for CS might causes complications or due to factors associated with indications of caesarean section and an added stress of anesthesia. ${ }^{25}$ In vaginal delivery fetus chest might be squeezed during passes through the birth canal which might evacuate secretion which in turn reduces the chance of developing birth asphyxia, while in cs this physiological advantage is not seen. But some studies shows insignificant relationship between mode of delivery and birth asphyxia. In this study out of 100 patients in the study group, 64 patients delivered vaginally, while 36 patients underwent lower segment caesarean section. In the control group, 68 patients delivered vaginally and the rest 32 patients had LSCS. Sarocoglue et al studied acute asphyxia, chronic asphyxia and compared with the control group. ${ }^{8}$

In their study, caesarean rate was $57.14 \%$ in the chronic fetal distress group, $90-91 \%$ in the acute fetal distress group and $26.67 \%$ in the control group. In the study by Ghosh B et al out of 26 patients in the study group 17 i.e. $65.38 \%$ delivered vaginally and 9 i.e. $34.61 \%$ delivered by LSCS. $^{7}$ Out of 49 patients in the non-asphyxiated group 34 patients delivered vaginally (i.e. 69.38\%) and 15 patients i.e. $30.61 \%$ delivered by LSCS. In the present study done in $\mathrm{PMCH}$, the case and the control group were comparable on the basis of mode of delivery ( $\mathrm{P}>0.05)$. So, we can assume that the mode of delivery does not have any significant effect on fetal asphyxia in this study.

\section{CONCLUSION}

Perinatal asphyxia remains one of the most significant cause of mortality and morbidity among new born due to hypoxic ischemic injury to the neonatal brain. Therefore, providing good quality medical care is of utmost importance to curtail the neonatal mortality and future complications of perinatal asphyxia. In this study, it was attempted to identify the determinants of birth asphyxia among newborns so that efforts should be made to improve the quality of intra-partum care service in order to prevent perinatal asphyxia and its long term complications. Although no significant relationship was established in the index study it is recommended that a study with a larger sample size may lead to more significant outcomes in futures studies.

Funding: No funding sources Conflict of interest: None declared

Ethical approval: The study was approved by the Institutional Ethics Committee

\section{REFERENCES}

1. World Health Organization and Others, Guidelines on Basic Newborn Resuscitation. World Heal Organ. 2012.

2. Lincetto O. Birth Asphyxia- Summary of the Previous Meeting and Protocol Overview. 2007.

3. WHO, World Health Statistics, WHO, Geneva, Switzerland. 2015.

4. Lei H, Peeling J. Effect of temperature on the kinetics of lactate production and clearance in a rat model of forebrain ischemia. Biochem Cell Biol. 1998;76(2-3):503-9. 
5. Penrice J, Lorek A, Cady EB, Amess PN, Wylezinska M, Cooper CE, et al. Proton magnetic resonance spectroscopy of the brain during acute hypoxia-ischemia and delayed cerebral energy failure in the newborn piglet. Pediatr Res. 1997;41(6):795-802.

6. Lei H, Berthet C, Hirt L, Gruetter R. Evolution of the neurochemical profile after transient focal cerebral ischemia in the mouse brain. J Cereb Blood Flow Metab. 2009;29(4):811-9.

7. Ghosh B, Mittal S, Kumar S, Dadhwal V. Prediction of perinatal asphyxia with nucleated red blood cells in cord blood of newborns. Int J Gynaecol Obstet. 2003;81(3):267-71.

8. Saracouglu F, Sahin I, Eser E, Gol K, Turkkani B. Nucleated red blood cells as a marker in acute and chronic fetal asphyxia. Int $\mathbf{J}$ Gynecol Obstet. 2000;71(2):113-8.

9. Qaiser DH, Sandila MP, Kazmi T, Ahmed ST. Influence of maternal factors on hematological parameters of healthy newborns of Karachi. Pak J Physol. 2009;5(2):34-7.

10. Boskabadi H, Afshari JT, Ghayour-Mobarhan M, Maamouri GH, Shakeri MT, Sahebkar A. Association between serum interleukin-6 levels and severity of perinatal asphyxia. Asian Biomedicine. 2010;4(1):79-85.

11. Clifford SH. High risk pregnancy I. Prevention of prematurity. The sin qua non for reduction in mental retardation and other neurological disorders. New Eng J Med. 1964;271(19):243-2.

12. Macdonald HM, Muligan JC, Allen AC, Taylor PM. Neonatal asphyxia I. Relationship of obstetric and neonatal complication to neonatal mortality in 38,405 consecutive deliveries Y Pediatr. 1980;96(5):898-902.

13. Papa D, Jyotsna P, Ashok BB. Cord blood nucleated red blood cell count-a marker of fetal asphyxia. J Obstet Gynecol India. 2008;58(1):45-4.

14. Pitsawong C. Risk Factors Associated with Bir th Asphyxia in Phramongkutklao Hospital. Thai J Obstet Gynaecol. 2011;19(4):165-71.

15. Solayman M, Hoque S, Akber T, Islam MI, Islam MA. Prevalence of Perinatal Asphyxia with
Evaluation of Associated Risk Factors in a Rural Tertiary Level Hospital. KYAMC J. 2017;8(1):43-8.

16. Tabassum F, Rizvi A, Ariff S, Soofi S, Bhutta ZA. Risk Factors Associated with Birth Asphyxia in Rural District Matiari, Pakistan: A Case Control Study. Int J Clini Med. 2014;5(21):1430-41.

17. Batra A, Sengupta A, Kumar A, Bhargava SK. A study of asphyxia neonatorum. Ind J Obstet Gynecol. 1988;38:162-6.

18. Uzel H, Kelekc S, Devecioglu C, Güneş A, Yolbaş İ, Şen V. Neonatal asphyxia: A study of 210 cases. J Clin and Exp Investi. 2012;3(2):194-8.

19. Chiabi A, Nguefack S, Evelyne MA, Nodem S, Mbuagbaw L, Mbonda E, Tchokoteu PF. Risk factors for birth asphyxia in an urban health facility in Cameroon. Iran J Child Neuro. 2013;7(3)46-54.

20. Gupta SK, Sarmah BK, Tiwari D, Shakya A, Khatiwada D. Clinical Profle of Neonates with Perinatal Asphyxia in a Tertiary Care Hospital of Central Nepal. J the Nepal Med Association. 2014;52(12):1005-9.

21. Ilah BG, Aminu MS, Musa A, Adelakun MB, Adeniji AO, Kolawole T. Prevalence and risk factors for perinatal asphyxia as seen at a specialist hospital in Gusau, Nigeria. Sub-Saharan Afr J Med. 2015;2(2):64

22. Kiyani AN, Khushdil A, Ehsan A. Perinatal factors leading to birth asphyxia among term newborns in a tertiary care hospital. Iran J pediat. 2014;24(5):637. PMID: 25793074.

23. Utomo MT: Risk factors for birth asphyxia. Folia Medica Indonesiana. 2011;47(4):211-4.

24. Nayeri F, Shariat M, Dalili H, Adam LB, Mehrjerdi FZ, Shakeri A. Perinatal risk factors for neonatal asphyxia in Vali-e-Asr hospital, Tehran-Iran. Iran J Reprod Med. 2012;10(2):137.

25. Harrison MS, Goldenberg RL. Cesarean section in sub-Saharan Africa. Maternal health, neonato and perinato. 2016;2(1):6.

Cite this article as: Sambedna, Kumar A, Chakore R. Outcomes and analysis of elements and delivery strategies with neonatal respiratory distress. Int J Reprod Contracept Obstet Gynecol 2021;10:2001-5. 